\title{
The Development of a Knowledge Test on Transgender Patients' Care
}

\author{
Jonathan Hernández-Agosto ${ }^{1, * \mathbb{D}}$, Kyle Melin ${ }^{2}{ }^{\mathbb{D}}$, Jurynelliz Rosa-Vega ${ }^{2}$, Edgar Carlo-Frontera ${ }^{2}$, \\ Andrés Rodríguez-Ochoa ${ }^{2}$ and Darlene Santiago-Quiñones ${ }^{3}$ \\ 1 Curriculum and Institutional Effectiveness Evaluation Division, School of Pharmacy, University of Puerto \\ Rico, San Juan, PR 00936, USA \\ 2 Department of Pharmacy Practice, School of Pharmacy, University of Puerto Rico, San Juan, PR 00936, USA; \\ kyle.melin@upr.edu (K.M.); jurynelliz.rosa@upr.edu (J.R.-V.); edgar.carlo@upr.edu (E.C.-F.); \\ andres.rodriguez1@upr.edu (A.R.-O.) \\ 3 Department of Pharmacutical Sciences, School of Pharmacy, University of Puerto Rico, San Juan, PR 00936, \\ USA; darlene.santiago@upr.edu \\ * Correspondence: jonathan.hernandez12@upr.edu; Tel.: +1-(787)-758-2525 (ext. 5420)
}

Received: 20 July 2020; Accepted: 25 September 2020; Published: 1 October 2020

\begin{abstract}
The objective of this study was to develop an assessment instrument to measure the effects of a continuing education intervention on 3 domains in pharmacists' knowledge needed to provide pharmaceutical care for transgender patients: (1) foundations of gender-affirming care, (2) health disparities and the specific needs of transgender patients, and (3) hormone treatments for transgender patients. Multiple-choice questions were developed, and an initial item bank of 47 items was drafted. Item bank revision was conducted by content matter experts, while feedback from 8 practicing pharmacists was provided for face validity and further insights. A preliminary test, containing 42 items was administered to 64 pharmacists before and after a three-hour continuing education intervention. Cronbach's alpha coefficient yielded a value of 0.65 as a pre-test and 0.77 as a post-test. Items were less difficult to answer by participants after taking the three-hour continuing education, showing better discrimination among high and low performers in the instrument administration as post-test, as well as better correlation when comparing participants' performance in the overall score against item-level performance. Psychometric evidence supports further instrument examination, which can improve this tool to measure gains in pharmacists' knowledge related to the care of transgender patients.
\end{abstract}

Keywords: transgender; transgender care; pharmacy education; continuing education; test validation

\section{Introduction}

One of the biggest challenges researchers often face is how to develop a new instrument, especially when phenomena to be measured is not widely addressed in the literature and the development of a new tailored instrument becomes the best decision. Nonetheless, researchers must consider the relevance of the instrument they want to use to measure any construct or phenomena and place particular interest in research questions as well as the quality of the instrument [1]. In this context, quality can be defined by its validity, "the extent to which an instrument measures what it claims to measure", and by its reliability, "the extent to which an instrument can be expected to give the same measured outcome when measurements are repeated" [1,2].

Like any other academic field dedicated to the improvement of knowledge by means of research and data gathering, pharmacy education is often at the crossroads of the adoption of existing instruments and the development of new ones to measure health-related phenomena [1]. This communication 
presents the results of a group of PharmD students and researchers at the University of Puerto Rico School of Pharmacy (SOP) on the development of a new test to measure the effects of a three-hour continuing education (CE) course on the knowledge of pharmacists to provide pharmaceutical care for transgender patients.

It is thought that a lack of knowledge of health care providers may be a contributing factor to the health disparities transgender patients experience when compared to their cis-gender counterparts. In a recent survey of schools of pharmacy, a little over half indicated that transgender-related education is a topic that is currently addressed somewhere within the curriculum, and only $41.2 \%$ of schools included it as a required part of the curriculum [3]. Similarly, a 2016 survey of community pharmacy residents found that $72 \%$ were not educated about transgender patient issues in pharmacy school and only $36 \%$ felt confident in their ability to treat transgender patients [4]. The findings and others demonstrating the limited training of pharmacists in this area have led to several recent calls to incorporate transgender-related care education and training into pharmacy curricula [5-7].

In 2017, a study was conducted in Puerto Rico to assess practicing pharmacists' knowledge and attitudes in providing pharmaceutical care to transgender patients as well as the transgender patients' perception of pharmacist knowledge and attitude [8]. In this study, pharmacist knowledge was low, with few pharmacists being able to define the term "transgender" or correctly identify appropriate hormonal treatments. Transgender patient perceptions of pharmacist knowledge confirmed these findings, reporting pharmacists to be ill-informed about their healthcare needs. These findings led the University of Puerto Rico SOP to implement a CE course to address these knowledge deficits among practicing pharmacists.

Therefore, it became imperative to evaluate the effectiveness of the CE course to determine if it can contribute to improving pharmacists' knowledge of the needs of transgender patients as well as their ability to provide pharmaceutical care to these patients. Although transgender patients consistently report low provider knowledge as a barrier to care [9-11], we were unable to find an adequate or appropriate existing instrument to measure the cognitive features of pharmacist knowledge. Although several assessments for various healthcare providers have been developed for assessing knowledge of LGBT issues broadly speaking [12,13], most provided very little (or no) assessments specific to transgender care. Many reports regarding healthcare provider knowledge specific to transgender patients have been based on healthcare providers' self-assessments of their own knowledge $[4,14,15]$. Ultimately, this resulted in the need to create a new test to assess pharmacist knowledge on providing pharmaceutical care to transgender patients.

We hypothesized that the development of this test may result in a new valid and reliable instrument that allows for the assessment of pharmacists' knowledge to provide pharmaceutical care to transgender patients. As educators continue to develop educational interventions to address this knowledge deficit among practicing pharmacists, the development of a validated assessment may prove useful in ensuring such interventions are successful in meeting their intended goals. This communication presents the ongoing instrument development procedures and techniques that have been performed to develop an assessment of pharmacists' knowledge to provide pharmaceutical care to transgender patients. We also describe the capability and quality level of the measurements provided by the instrument at its current phase of development.

The primary goal of this study was to develop a test that enabled researchers to measure the effect of a CE intervention on 3 units in pharmacists' knowledge needed to provide pharmaceutical care for transgender patients: (1) foundations of gender-affirming care, (2) health disparities and the specific needs of transgender patients, and (3) hormone treatments for transgender patients. Herein, we describe the following steps: the conceptualization of target constructs of knowledge on pharmaceutical care for transgender patients, the development of the content of the initial item pool, the item pool revision and input of technical experts, cognitive interviews with a heterogeneous sample of pharmacists with a similar background to the target educational audience, the final selection of items for the pilot test, and determination of preliminary internal consistency [16-18]. 


\section{Materials and Methods}

\subsection{Methodology}

This section describes the research methodology and the technical aspects for this cross-sectional study and preliminary psychometrical evaluation that were considered and performed in the design, construction, and evaluation of a test to measure pharmacists' knowledge to provide pharmaceutical care to transgender patients. All subjects gave their informed consent for inclusion before they participated in the study. The study was conducted in accordance with the Declaration of Helsinki, and the protocol was approved by the Institutional Review Board protocol \# B0250119 in June 2019, at the Medical Sciences Campus of the University of Puerto Rico.

After confirming that there were no previously published instruments considered adequate or appropriate to address the phenomena intended to be measured, researchers adapted procedures from the three-phase process suggested by Boateng, Neilands, Frongillo, Melgar-Quiñonez, and Young (2018) in their article "Best Practices for Developing and Validating Scales for Health, Social, and Behavioral Research: A Primer to develop a new test" [19]. After a literature review, the first step in the design of this test was the conceptualization of target constructs of knowledge on pharmaceutical care to transgender patients and 3 domains in pharmacists' knowledge needed to provide pharmaceutical care for transgender patients were identified: (1) foundations of gender-affirming care, (2) health disparities and the specific needs of transgender patients, and (3) hormone treatments for transgender patients. The selection of these domains was based on previous findings from research describing the knowledge and attitudes of pharmacists in Puerto Rico regarding the care of transgender patients [8]. In the previously mentioned 2017 study, a wide variety of knowledge deficits were identified. A lack of understanding of fundamental concepts such as gender identity was evidenced, as well as poor knowledge related to the specific healthcare needs of transgender patients and health disparities they face. Additionally, only $4 \%$ and $2 \%$ of pharmacists could appropriately identify all hormonal treatments for transgender women and transgender men, respectively. Together, these results were used to inform the 3 domains to be addressed by the continuing education session and assessed by the test to be developed. The second step was the examination of the content to generate the initial pool of items. The current clinical guidelines for the care of transgender patients were used as the primary resource for item development $[10,20]$. For each of the 3 domains identified, multiple-choice questions were developed, and an initial item bank of 47 items was drafted. The use of multiple-choice items was used to measure the underlying latent knowledge construct as they can additionally account for, and isolate, item-specific measurement error, which can lead to more accurate research findings [16].

The third step entailed the consideration of the content validity to assess if the drafted items were appropriate to measure the 3 domains of pharmacists' knowledge needed to provide pharmaceutical care for transgender patients. This step was performed by means of a multidisciplinary approach were item bank revision was conducted by content matter experts, as well as other professionals related to the pharmaceutical care for transgender patients with different areas of expertise, that included: (1) pharmaceutical care, (2) curriculum and evaluation, (3) pharmacist professional CE, (4) clinical practice of gender-affirming care, and (5) theoretical frameworks on providing care for sexual and gender minorities. The multidisciplinary team of expert reviewers included practicing clinical pharmacists who provide care for transgender patients, an educational expert on curriculum and evaluation, an educational expert on continuing education for practicing professionals, and a public health expert with extensive experience working with sexual and gender minorities. For the content validity evaluation, the expert reviewers were sent a list of learning objectives for each domain, the 47-item bank, and instructions for completing a semi-structured evaluation which consisted of 6 validity considerations for each item. Reviewers then provided written feedback to the investigators which allowed for any additional feedback or comments they felt was appropriate. Following reviewers' recommendations, 14 items were modified, and 5 items were dropped, yielding a preliminary test of 42 items. Table 1 shows the item distribution per unit. 
Table 1. Item distribution per unit.

\begin{tabular}{ccc}
\hline Test Unit & Items & Total Items \\
\hline Unit 1 & $1-7$ & 7 \\
Unit 2 & $8-21$ & 14 \\
Unit 3 & $22-42$ & 21 \\
\hline
\end{tabular}

The fourth step of the process, after item development and expert judgment, was to perform cognitive interviews with a group of 8 licensed pharmacists, with a similar background and demographic characteristics to the target audience, with the purpose to address possible face validity issues. We wanted to evaluate through the opinion of this group if each item was aligned with the 3 domains, as well as the content relevancy, representativeness, and technical quality [19]. The group of pharmacists offered a variety of suggestions regarding those aspects which were incorporated into the instrument, resulting in an improvement in clarity, syntax, and overall technical quality. Also, they verbalized the mental process they think would be required to provide answers to those questions [19]. A copy of the 42 items Spanish instrument is included in Appendix A. As the fifth step, data collection on items was made in the form of pre- and post-test administrations. While this step does not correspond necessarily to usual validation procedures, as established before, we considered it important to highlight that this test was created primarily to measure pharmacists' knowledge to provide pharmaceutical care to transgender patients, as a result of a three hour CE activity, which was part of a research project of a group of students of the SOP. The three hour CE was split into 3 sections corresponding with the 3 previously mentioned domains: “Unit 1: Transgender Patient Care Introduction" reviewed basic concepts such as relevant terminology; "Unit 2: General Health Issues of Transgender Patients" covered health disparities and appropriate health screening activities for transgender patients; and "Unit 3: Hormone Replacement Therapy for Gender Affirmation" detailed the pharmacotherapy considerations that are used for gender affirmation.

The preliminary test, containing 42 items, was administered to 64 pharmacists before beginning the CE intervention (pre-test) in the same space as the CE. Participants were recruited when they arrived for the CE presentation and invited to participate in the pilot study of the knowledge test. Participants were first presented with an information sheet explaining their participation was voluntary as well as the study purpose and procedures. The pre-test also collected demographic information including age, sex, gender identity, geographic information, and previous training and experience related to transgender care. Researchers collected all pre-tests before the 3 - $\mathrm{h}$ CE session began. The same instrument was administered a second time (post-test) following the $\mathrm{CE}$ under identical testing conditions. Participants were given $30 \mathrm{~min}$ each to answer the pre- and post-tests. All instruments were pre-printed with matching codes for pre and post-tests to facilitate the paring of the responses in the final analysis.

The sixth step and final step completed and described in this communication consisted of applying statistical and psychometric procedures with the obtained results for instrument preliminary analysis. Measures such as item difficulty index (IDI), item discrimination (ID), item-total correlations (ITC), Cronbach alpha coefficient $(\alpha)$, and confidence intervals for the Cronbach alpha coefficient (CI- $\alpha)$ were computed, to determine initial reference values as well as measurement errors of the instrument. Microsoft Excel (2016), IBM SPSS Statistics for Windows, Version 21.0 (IBM Corporation, Armonk, NY, USA), Intellectus Statistics (Intellectus Statistics LLC, Palm Harbor, FL, USA) and Confidence Intervals (PSYCTC.org, London, England) for a Sample Cronbach alpha Coefficient Value were used for data cleansing, processing, and calculations. Data collection began in August 2019 and finished in November 2019.

\subsection{Inclusion and Exclusion Criteria}

Pharmacists who were (1) licensed to practice in Puerto Rico, (2) members of the Puerto Rico College of Pharmacists (a legal requirement for practice in Puerto Rico), and (3) reported currently 
practicing pharmacy in Puerto Rico were eligible to participate. No specific exclusion criteria were used aside from excluding those pharmacists who did not meet all three of the inclusion criteria.

\subsection{Sample Description}

All participants were licensed pharmacists practicing in Puerto Rico and attending a 3-h CE session on providing pharmaceutical care for transgender patients. A convenience sample was used where all participants at 2 identical CE offerings (one at the Annual Meeting of the Puerto Rico College of Pharmacists and the other offered at the SOP) could participate in the study. After the CE sessions were completed, data were available for 68 pharmacists, of which 64 completed the pre-test, and 58 completed the post-test. Paired data for both the pre- and post-test was available for a total of 54 pharmacists.

\section{Results}

\subsection{Demographic Characteristics of the Participants}

Most participants $60(88.2 \%)$ identified as heterosexual and cisgender $(7 \mathrm{men}(10.3 \%)$ and 53 women $(77.9 \%))$. The remaining participants $4(11.8 \%)$ did not answer that question. A total of $29(42.6 \%)$ participants worked in community pharmacy, $9(13.2 \%)$ in the pharmaceutical industry, $17(25.1 \%)$ in a variety of other scenarios, and $9(13.2 \%)$ did not indicate their practice area. Fifty-three $(77.9 \%)$ of participants had never received formal training related to transgender care. Only 7 (10.2\%) participants indicated they had previously received education on providing care for transgender patients, through CE programs, education as part of the pharmacy curriculum, conferences, or self-study, while $8(11.8 \%)$ did not indicate if they had received previous training in this area.

\subsection{Assessment of the Preliminary Instrument Results as Pre and Post-Test}

A total of 64 pharmacists participated in the administration of the instrument as a pre-test, and 58 participants in the post-test. Table 2 shows the results of the execution scores of each unit. A complete listing of average participant percentage scores for each item can also be found in Appendix B. The total maximum score that a pharmacist could obtain in this test was 1.00 (meaning 100\%).

Table 2. Test execution scores by type of administration and unit.

\begin{tabular}{ccccccccc}
\hline \multirow{2}{*}{ Statistic } & \multicolumn{2}{c}{ Unit 1 } & \multicolumn{2}{c}{ Unit 2 } & \multicolumn{2}{c}{ Unit 3 } & \multicolumn{2}{c}{ Overall Instrument } \\
\cline { 2 - 8 } & Pre-Test & Post-Test & Pre-Test & Post-Test & Pre-Test & Post-Test & Pre-Test & Post-Test \\
\hline $\bar{x}$ & 0.7299 & 0.8670 & 0.4944 & 0.6576 & 0.4449 & 0.7011 & 0.5089 & 0.7142 \\
$s$ & 0.216 & 0.156 & 0.135 & 0.144 & 0.135 & 0.170 & 0.1112 & 0.1251 \\
$\mathrm{CV}$ & $29.59 \%$ & $17.99 \%$ & $27.31 \%$ & $21.90 \%$ & $30.34 \%$ & $24.25 \%$ & $21.85 \%$ & $17.52 \%$ \\
\hline \multicolumn{7}{c}{$\bar{x}=$ mean; $s$ = standard deviation; CV = coefficient of variation. }
\end{tabular}

As observed, participants had their highest mean scores in Unit 1, "Introduction to the Care of Transgender Patients" (pre: 0.7299; post: 0.8670). An increase in mean scores also occurred in all units when comparing pre-test and post-test, as well as in the overall results. As shown in Figure 1, the coefficient of variation decreased in average variability or level of dispersion around the mean when comparing pre-test and post-test. As expected, these results show less variation in the post-test modality, since all participants received the same intervention, resulting in a more uniform "understanding" of the concepts being tested. 
Pre-test

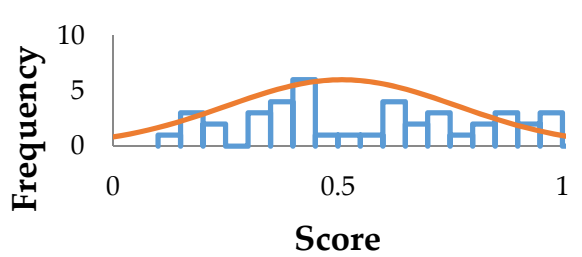

Post-test

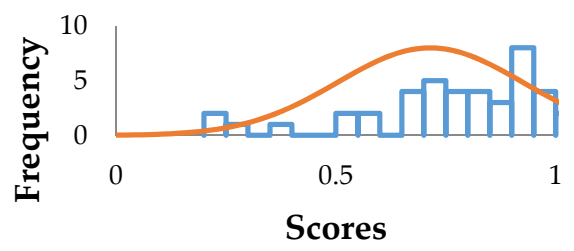

Figure 1. Pre- and post-test variability and spread.

\subsection{Basic Psychometrics, Internal Consistency, and Confidence Intervals}

Given that we are developing a new measurement instrument, it is important to determine the reliability of its scores, since it has an impact on the precision of the measurement results obtained by it [21]. Table 3 shows a summary of the results for the item difficulty index (IDI), item discrimination (ID), and item-total correlations (ITC). A complete listing IDI, ID, and ITC for each item can also be found in Appendix B.

Table 3. Summary of instrument assessment as pre and post-test.

\begin{tabular}{ccc}
\hline Statistical Test & Pre-Test & Post-Test \\
\hline IDI & $0.08-0.94$ & $0.16-0.98$ \\
\hline ID & 28 items $>0.20$ & 30 items $>0.20$ \\
\hline \multirow{2}{*}{ ITC } & 28 items $>0.20$ & 36 items $>0.20$ \\
\cline { 2 - 3 } & 10 items $0 \geq 0.19$ & 5 items $0 \geq 0.19$ \\
\cline { 2 - 3 } & 4 items $<0$ & 1 item $<0$ \\
\hline
\end{tabular}

IDI—-the item difficulty index; ID—item discrimination; ITC-item-total correlation.

As shown in Table 3, items were less difficult to answer by participants after taking the three-hour CE. Items also showed better discrimination among high and low performers in the instrument administration as post-test, as well as better correlation when comparing participants' performance in the overall score against item-level performance.

To review the uniformity of this test, Cronbach's alpha coefficient $(\alpha)$ analysis was performed to measure the internal consistency of the items in the instrument. The $\alpha$ values obtained for the preliminary instrument when administered as pre-test was $\alpha=0.65$ (CI 95\%: 0.52-0.76), and when administered as post-test was $\alpha=0.77$ (CI 95\%: 0.68-0.85). Table 4 shows a summary of the internal consistency and confidence intervals values by mode of administration and unit.

Table 4. Internal consistency and confidence intervals by mode of administration and Unit.

\begin{tabular}{ccc}
\hline \multirow{2}{*}{ Section } & $\alpha$ Pre-Test, (95\%: CI- $\alpha)$ & $\alpha$ Post-Test, $(95 \%:$ CI- $\alpha)$ \\
\cline { 2 - 3 } & $n=64$ & $n=58$ \\
\hline Overall instrument & $0.65 ;(0.52-0.76)$ & $0.77 ;(0.68-0.85)$ \\
Unit 1 & $0.54 ;(0.34-0.69)$ & $0.42 ;(0.16-0.62)$ \\
Unit 2 & $0.33 ;(0.06-0.55)$ & $0.43 ;(0.19-0.62)$ \\
Unit 3 & $0.50 ;(0.30-0.66)$ & $0.75 ;(0.65-0.83)$ \\
\hline
\end{tabular}

As shown in Table 4, overall internal consistency improved for the instrument when administered as a post-test modality. It also improved for every individual unit in the post-test administration, except for Unit 1. 


\section{Discussion}

Here we have presented the preliminary results in our validation process of a new instrument for measuring pharmacists' knowledge on the topic of providing pharmaceutical care to transgender patients. The instrument was developed because we were unable to find a validated instrument in the literature that adequately measures the cognitive features of pharmacist knowledge of transgender care.

As the results showed, the item difficulty index (IDI) showed an overall improvement, as expected, when comparing pre-test vs. post-test administrations of the instrument. The IDI is the percentage of respondents taking the test who answered the item correctly and where the larger the percentage of getting an item right, the easier the item [22]. An acceptable proportion of the instrument items showed a discrimination index (DI) of 0.20 or more ( $67 \%$ to $81 \%$ of the items), as well as item-total correlations (ITC) of 0.20 or more ( $67 \%$ to $86 \%$ of the items). Although a DI of 0.20 to 0.29 shows marginal items that may need some revision, this test has its majority over 0.20 , while 0.30 and greater are considered good or very good items [23,24]. It is also important to consider what the item intends to measure when analyzing discrimination, which means that looking only at the DI is not sufficient. For example, if the item is intended to measure common basic knowledge or skills that the population to be examined is supposed to master, then both high performers, as well as low performers, should obtain high scores on these kinds of items, which may lower the item discrimination index values, potentially to the point of no discrimination at all.

On the other hand, the ITC was used to find the predictive power of each individual item when compared to the total score. The ITC indicates a positive correlation between respondents' scores on the item and scores on the test, meaning that those who performed well on that specific item also performed well on the test, and conversely, those who performed poorly on that specific item also performed poorly on the test. Literature suggests that ITC may be useful to provide predictive validity of the total test [22].

When evaluating the Cronbach's alpha coefficient $(\alpha)$ of the test, these results showed differences among the $\alpha$ with repeated administrations. This is expected, even when it is the same instrument with mostly the same respondents as $\alpha$ values apply to each administration and should not be assumed to be a fixed feature of the scale or instrument [1]. These results compare to what other researchers have found, suggesting the same pattern of $\alpha$ improvement when performing repeated administrations of an instrument to the same population $[1,25,26]$.

To take into consideration the magnitude that $\alpha$ can undergo because of this variations, and due to the influence of the inherent measurement error [23], (especially with a small sample size), confidence intervals for the Cronbach alpha coefficient (CI- $\alpha$ ) were computed to improve instrument description in this preliminary assessment, determine the measurement precision of the coefficient for the population, and interpret the level of reliability while accounting for the sampling error in a statistical hypothesis test framework [21]. The CI- $\alpha$ also allows the reader to keep in mind that, as all statistical estimates are affected by sampling error (including reliability), $\alpha$ tests "do not possess absolute or invariant reliability across the samples" [27], particularly with a sample of the aforementioned size, which makes it necessary to calculate its CI- $\alpha$.

In this particular scenario, when the preliminary instrument was administered as a pre-test, the results showed that for any random sample of size 64 from an infinitely large population in which $\alpha=0.65$, the expected $\alpha$ can be expected to be between $0.52-0.76$, when calculating the CI- $\alpha$ at $95 \%$ certainty for the observed $\alpha$ [28]. On the other hand, when the preliminary instrument was administered as a post-test, the results show that for any random sample of size 58 from an infinitely large population in which $\alpha=0.65$, the expected $\alpha$ may be between $0.68-0.85$, when calculating the CI- $\alpha$ at $95 \%$ certainty for the observed $\alpha$ [28].

It is very common to use distinct attributes, or labels, to describe how appropriate the internal consistency of an instrument is based on the $\alpha$ values. However, there is evidence that suggests a wide and diverse list of terms that can be used to interpret them, supporting that there is no clear consensus on the most appropriate labels to use to describe the values obtained when calculating $\alpha$ [1]. 
Furthermore, other researchers have suggested that there is no general level (such as 0.70 ) where $\alpha$ becomes acceptable, but rather that instruments with quite a low value of alpha can still prove been useful in some circumstances [1,29].

With those main considerations in perspective, in this study, the internal consistency coefficients for pre- and post-tests are considered as informative, not final values. However, it is the intention that these values provide a better understanding of instrument capabilities. It is relevant to keep in mind that this test includes specialized items to measure different components of pharmacists' knowledge to provide pharmaceutical care to transgender patients, which can result in lower $\alpha$ value because of the possible multidimensionality of the items [1].

Another issue that needs to be accounted for when reviewing and interpreting internal consistency is that the sample size, at this point, is still small $(n=64)$. There is literature that suggests at least 300 participants for each scale or an ideal ratio of respondents to items of ten to one (10:1) [19], which means that for this test, at least 300 or a total of 420 respondents may be necessary ( 42 items $\times 10$ participants each $=420$ respondents). Thus far, the test has been administrated to only 64 participants, and increasing the sample size would likely provide a more accurate measure of internal consistency.

With all these aspects already presented, we can certainly affirm that at this point, the overall process has several limitations. First, the results were obtained in a convenience sample of pharmacists who participated in a CE activity and agreed to complete the test. Consequently, this sample is not representative of the entire pharmacist population in Puerto Rico. Second, the sample size requirement is not yet fulfilled. Hence, future steps on continuing the development and validation of this instrument will require an increase in sample size and completion of the validation process by means of doing an Exploratory Factor Analysis (EFA), item reduction process, Confirmatory Factor Analysis (CFA), and test of dimensionality, reliability, and convergent validity.

Despite these limitations, we believe these preliminary results are indicative of an instrument that has the potential to be useful in evaluating pharmacist knowledge needed to provide pharmaceutical care to transgender patients. With the limited incorporation of such content in PharmD curricula today, it is imperative that educational interventions be provided to both PharmD students and practicing pharmacists to improve the collective capacity of the pharmacy profession to adequately care for transgender patients. However, as such educational interventions are developed and implemented, their effectiveness in improving pharmacist knowledge should be assessed. Such assessment is paramount ensuring the quality of such interventions and, ultimately, their ability to improve the care that transgender patients receive. The instrument developed and described here may be of use in evaluating continuing education interventions for practicing pharmacists. Additionally, it may also have the potential to assist in assessing the current knowledge of pharmacists and other healthcare providers in different communities and health systems.

\section{Conclusions}

In this communication, we present a new test that was developed to assess pharmacist knowledge related to pharmaceutical care for transgender patients and the preliminary validation procedures and results for the instrument. The basic psychometric properties of the test are encouraging and demonstrate that the test has the potential to result in a new, valid, and reliable instrument to assess pharmacists' knowledge on this topic. Preliminary results showed the possibility of measuring changes in pharmacists' knowledge related to the care of transgender patients, as the results of the pre- and post-tests showed a mean increase in performance of $20.42 \%(p<0.001)$, with improvements observed in each of the three units assessed. The instrument has the potential to discriminate between the performance level of respondents, while the Cronbach's alpha coefficient $(\alpha)$ preliminary analysis described a consistent instrument of measurement. As the profession of pharmacy grapples with the task of improving practicing pharmacists' knowledge and ability to provide care for transgender patients, the psychometric evidence presented here supports the potential use of this test as a useful tool for measuring the effectiveness of educational interventions in this area. As such, further validation of 
the instrument is warranted as additional educational interventions for pharmacists are implemented on this topic.

Author Contributions: Conceptualization: K.M., E.C.-F., A.R.-O., J.R.-V., and D.S.-Q.; methodology, software, validation, and formal statistical analysis: J.H.-A.; continuing education intervention, K.M., E.C.-F., A.R.-O., J.R.-V., and D.S.-Q.; writing — original draft preparation, K.M. and J.H.-A.; funding acquisition, K.M. and D.S.-Q. All authors have read and agreed to the published version of the manuscript.

Funding: The work of K.M. and D.S.-Q. was partially supported by The National Institute of Health Award Numbers: HCTRECD R25MD007607 and HiREC S21MD001830 from the National Institute on Minority Health and Health Disparities.

Acknowledgments: We wish to acknowledge the support and participation of Marlene McClosky-Oliver, who work in the Continuing Education and Professional Studies Division of the School of Pharmacy of Puerto Rico, whose active participation on reviewing the instrument, as well as facilitating the continuing education intervention, made a substantial contribution to this project. We would also like to acknowledge Sergio Baerga Maldonado, Nelly Conte Schmidt, and Carlos Rodriguez-Diaz for their assistance in reviewing the initial instrument.

Conflicts of Interest: The authors declare no conflict of interest. The funders had no role in the design of the study; in the collection, analyses, or interpretation of data; in the writing of the manuscript, or in the decision to publish the results. 
Appendix A. Spanish Version of the Instrument with 42 Items (Pre-Test Copy)

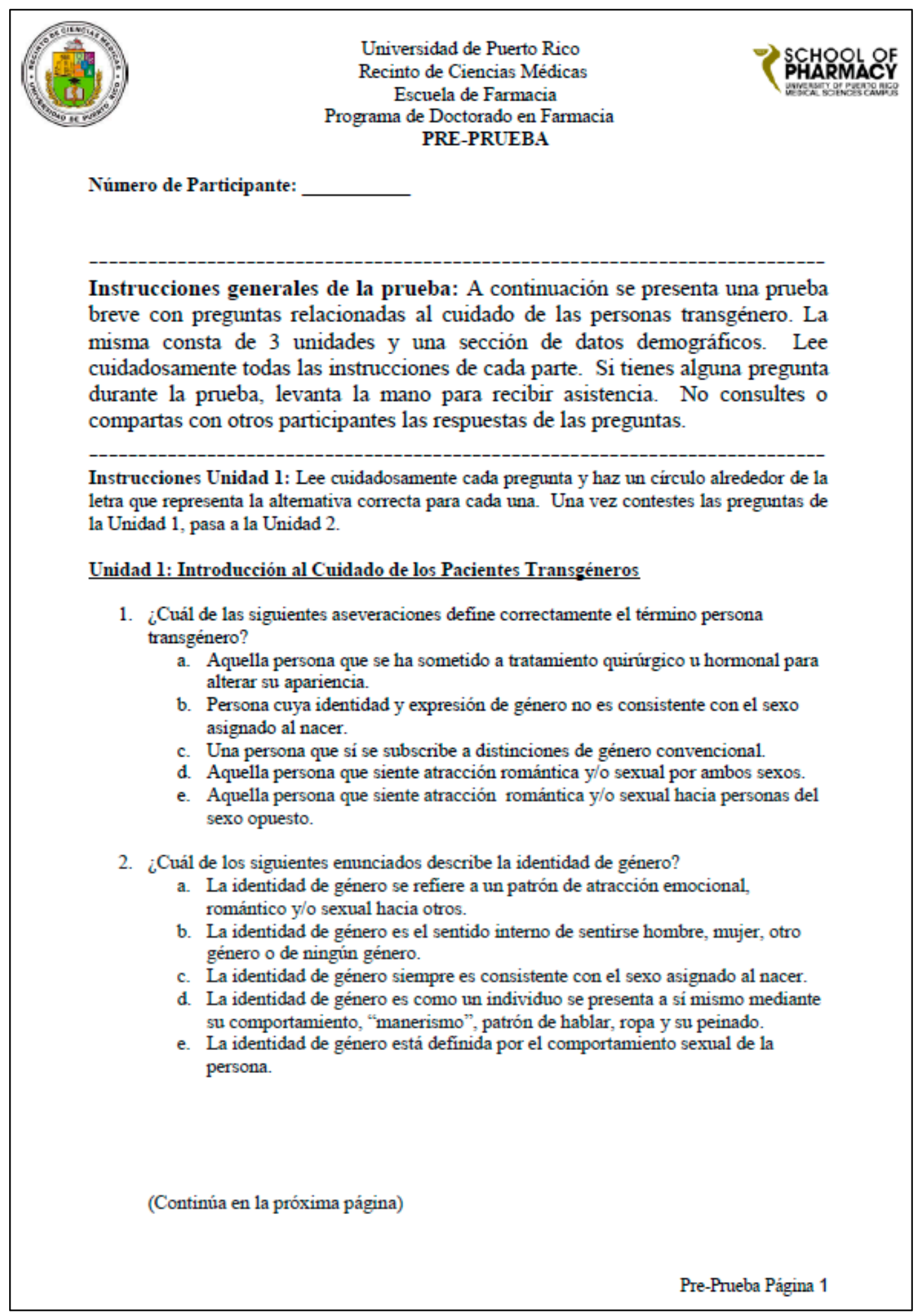


3. ¿Cuál de las siguientes aseveraciones es correcta?

a. E1 término expresión de género se define como atracción romántica o sexual a personas del sexo opuesto, del mismo sexo o género, o de ambos sexos.

b. Todas las personas transgénero desean completar procesos de afirmación genital o terapia de reemplazo hormonal.

c. Para que una persona se identifique como transgénero debe expresar su identidad de género de forma distinta a la esperada de acuerdo al sexo que se le asignó al nacer.

d. Una persona transgénero es aquella que no se siente del género contrario pero adopta los atuendos y comportamientos relacionados con ese género.

e. Ninguna de las anteriores

4. Una persona que se identifica como hombre, pero al nacer le fue asignado el sexo de mujer, se reconoce como:
a. Mujer transgénero
b. Género Queer
c. Mujer cisgénero
d. Hombre cisgénero
e. Hombre transgénero

5. Una persona que se identifica como mujer, pero al nacer le fue asignado el sexo de hombre, se reconoce como:
a. Mujer transgénero
b. Mujer cisgénero
c. Hombre cisgénero
d. Hombre transgénero
e. Género Queer

6. ¿Cuál de las siguientes alternativas representa la manera en la que una persona transgénero puede expresar su identidad de género?
a. Cirugia
b. Maquillaje
c. Terapia de reemplazo hormonal
d. Manera de hablar
e. Todas las alternativas son correctas

7. ¿Cuál de los siguientes servicios debe ofrecer el farmacéutico a pacientes transgénero?

a. Terapia de conversión

b. Diagnosticar un paciente con disforia de género

c. Identificar y manejar interacciones droga a droga relacionada a la terapia hormonal.

d. Ofrecer examen de Papanicolaou

e. Despachar la terapia de reemplazo hormonal sin una receta médica

(Continúa en la próxima página) 
Instrucciones Unidad 2: Lee cuidadosamente cada pregunta y haz un circulo alrededor de la letra que representa la altemativa correcta para cada una. Una vez contestes las preguntas de la Unidad 2, pasa a la Unidad 3.

Unidad 2: Otros Problemas de Salud de los Pacientes Transgéneros

1. ¿Cuál de las siguientes es una disparidad social y de salud que enfrentan las personas transgénero?

a. Desvinculación de redes de apoyo

b. Amplio acceso a servicios de salud

c. Aumentar el riesgo a desarrollar tumores malignos en el cerebro

d. Fácil acceso a profesionales de la salud capacitados en el cuidado hacia personas transgénero

e. Disponibilidad de espacios seguros e inclusivos en el escenario de salud

2. ¿Cuál de los siguientes enunciados es cierto?

a. La probabilidad de que una persona transgénero utilice hormonas obtenidas sin receta médica es baja.

b. Se ha demostrado que el apoyo familiar no influye en la calidad de vida de una persona transgénero.

c. Las cirugias para afirmación genital son accesibles en Puerto Rico.

d. La transfobia no afecta el cuidado de la salud de un paciente transgénero.

e. Alrededor de $25 \%$ de la población transgénero no puede pagar por servicios de salud.

3. ¿A qué dificultad podria enfrentarse una persona transgénero que desea realizarse una cirugia de afirmación de género?

a. Aumento en el costo de la cubierta de su plan médico

b. Alto riesgo de muerte durante la cirugía

c. Falta de profesionales dispuestos

d. Alto riesgo de complicaciones luego de la cirugía

e. Todas las anteriores

\section{ESTE ESPACIO SE HA DEJADO EN BLANCO INTENCIONALMENTE.}

(Continúa en la próxima página) 


\section{Utiliza el siguiente caso para contestar las preguntas 4 y 5 .}

AA es una persona transgénero que visita la farmacia. En su última visita ella le contó que lleva un año auto-administrándose hormonas que consiguió con la ayuda de su amiga. AA dice que se siente bien, pero visita la farmacia porque se enteró que su amiga está "malita del corazón" y se preocupó que le fuera a suceder lo mismo a ella.

4. Las acción que llevaría a cabo como farmacéutico/a con AA es:

a. Preguntarle a AA sobre las barreras que ha encontrado para usar hormonas bajo supervisión médica y referirla a cuidado médico para afirmación de género.

b. Indicarle a AA que si se siente bien no debe preocuparse, ya que si tuviera una enfermedad cardiovascular el/ella presentaria signos y sintomas de la misma.

c. Decirle AA que como está utilizando hormonas también va a padecer de una condición cardiovascular y la única manera para evitar esto es descontinuar el tratamiento hormonal.

d. Recomendarle a AA que se siga administrando hormonas sin ninguna supervisión médica, ya que esto no va a afectar su salud.

e. Decirle a AA que no se debe asustar y que para evitar una complicación cardiovascular se tome $81 \mathrm{mg}$ de aspirina diaria.

5. Partiendo del caso anterior, si AA también indica que hace dos años perdió su trabajo, que actualmente practica el trabajo sexual a cambio de dinero y que no tiene ningún tipo de red de apoyo, ¿cuál de las aseveraciones correcta?

a. AA tiene el mismo riesgo a contraer una ITS o sufrir de ideación suicida que cualquier otra persona transgénero.

b. Como farmacéutico debo llamar a la policía ya que el trabajo sexual es ilegal en Puerto Rico.

c. La auto-administración de hormonas junto con la falta de red de apoyo aumenta el riesgo de que AA sufra algún tipo de complicación de salud.

d. Como farmacéutico/a tengo el deber decirle a AA que busque el centro más cercano donde ofrecen terapia de conversión para que curen a AA.

e. AA no sufre de disparidades sociales y de salud.

6. ¿Cómo los farmacéuticos pueden crear un ambiente inclusivo para pacientes transgénero?

a. Entrenar un empleado en cuidado farmacéutico culturalmente competente y dirigir todos los pacientes transgéneros a dicho empleado.

b. Evitar hacer preguntas personales que no son relevantes al cuidado del paciente.

c. No hacer preguntas respecto a nombres ni pronombres preferidos para evitar avergonzar a los pacientes.

d. No mostrar material educativo dirigido a la comunidad LGBT para proteger la privacidad de todo paciente transgénero.

e. Insistir que los empleados utilicen o se refieran al paciente únicamente por el nombre que aparece en la tarjeta de identificación sin importar la preferencia del paciente. 
7. ¿Cuál de las siguientes pruebas de cernimiento le debo recomendar a mujeres transgénero?
a. Cáncer cervical
b. Cáncer de endometrio
c. Cáncer de colon
d. Cáncer de ovario
e. Cáncer de higado

8. ¿Cuál de las siguientes pruebas de cernimiento le debo recomendar a hombres transgénero?
a. Cáncer de próstata
b. Cáncer cervical
c. Cáncer de hueso
d. Cáncer de pulmón
e. Leucemia

9. La prueba de cernimiento de densidad mineral ósea se debe considerar en todo paciente:
a. Que utilice terapia de reemplazo hormonal con testosterona
b. Que utilice terapia de reemplazo hormonal con estrógeno
c. Que utilice terapia de reemplazo hormonal con agonista de la hormona liberadora de gonadotropina
d. Que sea mayor de 65 años de edad
e. Que utilice terapia de reemplazo hormonal con spironolactone

10. ¿Qué pacientes deben recibir una prueba de Papanicolaou anual como cernimiento para detectar cáncer cervical?

a. Mujer transgénero que no se ha realizado cirugia de afirmación de género

b. Hombre cisgénero

c. Hombre transgénero que no se ha realizado cirugia de afirmación de género

d. Todas las anteriores

e. Ninguno de los anteriores

11. ¿Qué pacientes deben recibir una evaluación anual para detectar cáncer de mama?

a. Mujer transgénero de 50 años de edad que ha recibido terapia hormonal por los pasados 20 años

b. Hombre transgénero que se realizó la mastectomia

c. Hombre cisgénero

d. No es recomendable hacer pruebas para detectar cáncer de mama

e. Ninguno de las anteriores

12. ¿Qué pacientes deben ser monitoreados para detectar cáncer?
a. Mujer cisgénero
b. Hombre transgénero que ha recibido terapia hormonal por los pasados 10 años
c. No es recomendable hacer pruebas para detectar cáncer de próstata
d. Mujer transgénero de 55 años de edad
e. Ninguno de las anteriores 
13. ¿Cuál de los siguientes enunciados describe una de las disparidades que enfrenta la población transgénero?

a. Las personas transgénero tienen una amplia red de apoyo en Puerto Rico.

b. Las personas transgénero reportan menos condiciones crónicas tales como asma, dolor de cabeza, alergias, osteoartritis y problemas gastrointestinales al compararse con la población cisgénero.

c. Una persona transgénero tiene el doble de probabilidad de haberse realizado un chequeo médico en el último año al compararse con una persona cisgénero.

d. Es más probable que las personas transgénero sean adineradas al compararse con personas cisgéneros.

e. Es menos probable que las personas transgénero tengan seguro médico y que reporten sus necesidades de salud al compararse con la población cisgénero.

14. Las disparidades de salud:

a. Solamente son más altas en personas transgénero que viven en áreas rurales donde hay menor cantidad de proveedores de salud

b. No impactan a las personas transgénero ya que hay programas y clínicas de salud designadas para esta población

c. Están asociadas a experiencias de discriminación y prejuicios debido a su identidad de género.

d. Son equivalentes entre los pacientes transgénero y pacientes cisgéneros

e. No existen en Puerto Rico

ESTE ESPACIO SE HA DEJADO EN BLANCO INTENCIONALMENTE.

(Continúa en la próxima página) 
Instrucciones Unidad 3: Lee cuidadosamente cada pregunta y haz un circulo alrededor de la letra que representa la altemativa correcta para cada una. Una vez contestes las preguntas de la Unidad 3, pasa a la sección de Datos Demográficos.

\section{Unidad 3: Terapia Hormonal para la Transición de Género}

1. ¿Cuál de las siguientes alternativas presenta el orden correcto de pasos del proceso de transición de género de una persona transgénero?

a. Evaluación psicológica $\rightarrow$ hormonas $\rightarrow$ cirugia genital

b. Evaluación psicológica $\rightarrow$ cirugia genital $\rightarrow$ hormonas

c. Hormonas $\rightarrow$ evaluación psicológica $\rightarrow$ cirugia genital

d. Cirugia genital $\rightarrow$ hormonas $\rightarrow$ evaluación psicológica

e. Según los estándares de cuidado se puede permitir que cada persona transgénero busque sólo aquellas intervenciones que desean para afirmar su propia identidad de género.

2. ¿Cuál es el beneficio de iniciar terapia con reemplazo hormonal antes de la pubertad?

a. Disminuye la probabilidad de fallo terapéutico de la terapia de reemplazo hormonal.

b. Evita el desarrollo de caracteristicas que se vuelven permanentes al finalizar la pubertad.

c. Aumentan los efectos secundarios producidos por la terapia de reemplazo hormonal luego de la pubertad.

d. Reduce la dosis que se requiere para lograr el efecto deseado.

e. Permite tener un mayor número de altemativas de tratamiento.

3. ¿Cuán frecuente en el primer año de tratamiento se debe monitorear a un/a paciente transgénero que comenzó con terapia de reemplazo hormonal?
a. Cada mes
b. Cada 2 a 3 meses
c. Cada 4 a 6 meses
d. Cada 8 a 12 meses
e. Cada 2 años

4. ¿Cuál de las siguientes alternativas es importante discutir con la persona transgénero antes de comenzar el tratamiento de reemplazo hormonal?

a. Si tiene planes de reproducción y ofrecerle las alternativas disponibles

b. Si desea contraer matrimonio en un futuro

c. Si ha considerado como su tratamiento hormonal afectaría su familia

d. Si ha considerado como su tratamiento hormonal afectaría su trabajo

e. No es importante discutir con la persona transgénero ninguna de las alternativas anteriores

(Continúa en la próxima página) 
5. Un paciente que desea comenzar a utilizar tratamiento de reemplazo hormonal para afirmación de género debe tener resultados base ("baseline") de laboratorio de:
a. $\mathrm{CBC}$ con diferencial, prueba de tuberculosis, y función renal
b. Enzimas hepáticas, glucosa, TSH, y PSA
c. Función renal, glucosa, $\mathrm{AlC}$, lipidos, y prueba de VIH
d. Enzimas hepáticas, glucosa, A1C, lipidos, electrolitos y función renal
e. Electrolitos, prueba de tuberculosis, CBC con diferencial, y PSA

6. DD es una persona transgénero y desea utilizar tratamiento de reemplazo hormonal para afímación de género. De los siguientes documentos, ¿cuál es necesario para que el farmacéutico despache el tratamiento hormonal?
a. Carta de referido de un proveedor de servicios de salud mental
b. Consulta con un cardiólogo
c. Receta de un médico
d. Prueba de tuberculosis
e. Prueba para detección de cáncer colon

7. De acuerdo a las actuales prácticas de farmacia en Puerto Rico, ¿cuál terapia NO es adecuada para una mujer transgénero que utiliza terapia hormonal?
a. Estradiol
b. Etinilestradiol
c. Inhibidor de $5 \alpha$-reductase
d. Medroxiprogesterona
e. Agonista de la hormona liberadora de gonadotropina

8. De acuerdo a las prácticas actuales en cuidado farmacéutico en Puerto Rico, la terapia adecuada para hombres transgéneros incluye la siguiente opción:
a. Medroxiprogesterona
b. Inyección intramuscular de testosterona
c. Agonista de la hormona liberadora de gonadotropina
d. Espironolactona
e. Finasteride

9. Como farmacéutico/a, ¿qué alternativa terapéutica $\underline{\text { NO }}$ debo recomendar a un paciente transgénero?
a. Hormonas supresoras de pubertad
b. Terapia hormonal
c. Depilación facial
d. Terapia de conversión
e. Intervención para la modificación del habla comunicación, y adaptaciones de comportamiento

10. ¿Qué producto se prefiere para una mujer transgénero con alto riesgo de enfermedad tromboembólica?
a. Testosterona intramuscular
b. Estradiol transdérmico
c. Estradiol intramuscular
d. Estradiol vaginal
e. Testosterona transdérmica 
11. Un efecto adverso común del uso de terapia de estrógeno es:
a. Pérdida de peso
b. Disminución en la presión sanguinea
c. Disminución en la resistencia a insulina
d. Calentones
e. Acné

12. Entre los efectos relacionados al uso de estrógeno se encuentran:

a. Aumento en el libido, disminución del tamaño del clítoris

b. Atrofia vaginal

c. Redistribución de la grasa corporal, crecimiento del tejido mamario

d. Aumento de la producción de esperma, reducción del tamaño de los testículos

e. Disminuye la densidad ósea

13. Entre los efectos relacionados al uso de testosterona se encuentran:
a. Aumenta el flujo menstrual
b. Reducción del tamaño de los testículos y disminuye en la producción de esperma
c. Resequedad de la piel, disminución del tamaño del clitoris, reducción de la masa corporal
d. Disminución del libido y aumento de riesgo de tromboembolismo
e. Cambio en la voz, crecimiento del vello facial, atrofia vaginal

14. En un paciente utilizando hormonas masculinizantes se debe medir el nivel de testosterona cada meses en el primer año.
a. 1 a 2 meses
b. 2 a 3 meses
c. 3 a 4 meses
d. 4 a 5 meses
e. 6 a 12 meses

15. La dosis de estrógeno en una persona transgénero se regula de acuerdo a los niveles de:
a. Testosterona
b. Hormona luteinizante
c. Estradiol
d. Hormona liberadora de gonadotropina
e. Prolactina

16. Para que el tratamiento de estrógeno sea efectivo, el nivel de testosterona en sangre debe de ser.
a. $<55 \mathrm{ng} / \mathrm{d} 1$
b. $<65 \mathrm{ng} / \mathrm{dl}$
c. $<85 \mathrm{ng} / \mathrm{dl}$
d. $<95 \mathrm{ng} / \mathrm{dl}$
e. $<125 \mathrm{ng} / \mathrm{dl}$

(Continúa en la próxima página) 
17. Como profesional de salud debo tener un récord médico inclusivo para personas transgéneros en el cual se incluya lo siguiente, EXCEPTO:

a. E1 uso de condón en un encuentro sexual

b. Nombre de preferencia del paciente

c. Si desea hacerse una operación de afirmación genital

d. Nombres de parejas sexuales del paciente

e. Orientación sexual del paciente

18. ¿Cuáles son los resultados de laboratorios que se ven afectados de acuerdo a la configuración hormonal actual (expresión de género actual) de una persona transgénero que ha utilizado terapia de reemplazo hormonal por 2 años?
a. "Prostate Specific Antigen" (PSA)
b. "Thyroid Stimulating Hormone" (TSH)
c. Aclaramiento de creatinina ("creatinine clearance")
d. Potasio
e. Hemoglobina A1C

19. AM es un hombre transgénero en terapia con testosterona que llega a mi farmacia para recoger sus medicamentos. Al despachar los medicamentos me doy cuenta que uno de ellos es un medicamento teratogénico. Como farmacéutico/a pienso que:

a. No es necesario realizar una consulta al despachar un medicamento teratogénico a AM, ya que él no puede concebir hijos/as.

b. AM debe de recibir una consulta y ser orientado antes de recibir el medicamento teratogénico aunque esté recibiendo terapia con testosterona.

c. AM no puede recibir ningún medicamento teratogénico ya que está contraindicado.

d. Debo negar el despacho del medicamento por seguridad del paciente.

e. AM no necesita utilizar ningín método anticonceptivo ya que está recibiendo terapia de reemplazo hormonal con testosterona.

20. ¿Qué tan pronto debe ser evaluada una persona transgénero luego de haber comenzado a utilizar la terapia de reemplazo hormonal?
a. 3 semanas después
b. 6 semanas después
c. 8 semanas después
d. 3 meses después
e. 6 meses después

21. ¿Para cuál de los siguientes pacientes está indicada la densitometria ósea (BDM)?

a. Mujer transgénero de 18 años recibiendo hormonas feminizantes

b. Hombre transgénero de 45 años que recibió hormonas masculinizantes hace 30 años

c. Mujer trans género de 66 años de edad

d. Se debe considerar en todos los pacientes que reciben terapia de reemplazo hormonal

e. Se debe considerar en todas las mujeres transgénero que estén recibiendo hormonas feminizantes 


\section{Datos Sociodemográficos}

Instrucciones: A continuación encontrarás algunas preguntas generales sobre datos sociodemográficos. Lee cuidadosamente y selecciona o escribe la mejor contestación a las preguntas en el espacio provisto. Toda la información que brindes es confidencial y NO te identifica en tu carácter individual.

1. ¿Usted participó del estudio piloto para la validación de esta prueba? $-\mathrm{Si}$

- No

2. ¿Cuál es su escenario de trabajo como farmacéutico?

Farmacia de Comunidad

Farmacia Especializada

- Farmacia de Hospital

Industria Farmacéutica

- Otro, especifique:

3. ¿En qué municipio trabaja? (Puede mencionar más de uno)

4. ¿En qué pueblo vive actualmente?

5. ¿Qué edad tiene? años

6. ¿Con cuál sexo se identifica? Hombre

- Mujer

7. ¿Con cuál género se identifica?

Masculino

- Femenino

- Transgénero

- Otro, especifique:

FIN DE LA PRUEBA. POR FAVOR, ENTREGA LA MISMA A ALGUNO DE LOS ADMIIISTRADORES DE LA MISMA.
8. ¿Cómo identifica su orientación sexual actual?

Heterosexual

- Homosexual/Lesbiana

Bisexual

_Otro: Especifique:

9. ¿Ha recibido adiestramiento formal para atender a personas transgénero? Si su contestación es

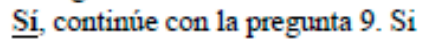
su contestación es $\mathrm{No}_{0}$, omita las próximas preguntas y entregue la prueba a alguno de los administradores.

- ${ }_{\text {No }}^{\mathrm{Si}}$

10. Qué tipo de adiestramiento recibió? (Seleccione todas las que apliquen)

_Educación continua

Educación como parte del

currículo de farmacia

Educación en línea

- Conferencias

- Autoestudio

_Otro: Especifique:

11. Aproximadamente, ¿cuánto tiempo en horas ha dedicado a capacitarse en asuntos de salud de personas transgénero? 
Appendix B. Items by Unit in Pre and Post-Test

\begin{tabular}{|c|c|c|c|c|c|c|c|c|c|c|c|}
\hline \multirow{2}{*}{ Unidad } & \multirow{2}{*}{ Item } & \multicolumn{5}{|c|}{ Pre-Prueba } & \multicolumn{5}{|c|}{ Post-Prueba } \\
\hline & & $\bar{x}$ & SD & IDI & ID & ITC & $\bar{x}$ & SD & IDI & ID & ITC \\
\hline \multirow{7}{*}{$\begin{array}{l}\text { Unidad 1: Introducción } \\
\text { al Cuidado de los } \\
\text { Pacientes Transgénero }\end{array}$} & K 1.1 & 0.63 & 0.49 & 0.63 & 0.29 & 0.30 & 0.98 & 0.13 & 0.98 & 0.06 & 0.08 \\
\hline & K 1.2 & 0.89 & 0.31 & 0.89 & 0.24 & 0.32 & 0.86 & 0.35 & 0.86 & 0.19 & 0.21 \\
\hline & K 1.3 & 0.56 & 0.50 & 0.56 & 0.29 & 0.31 & 0.69 & 0.47 & 0.69 & 0.44 & 0.36 \\
\hline & K 1.4 & 0.59 & 0.50 & 0.59 & 0.65 & 0.45 & 0.79 & 0.41 & 0.79 & 0.25 & 0.20 \\
\hline & K 1.5 & 0.59 & 0.50 & 0.59 & 0.76 & 0.56 & 0.84 & 0.37 & 0.84 & 0.25 & 0.26 \\
\hline & K 1.6 & 0.91 & 0.29 & 0.91 & 0.00 & 0.07 & 0.95 & 0.22 & 0.95 & 0.06 & 0.18 \\
\hline & K 1.7 & 0.94 & 0.24 & 0.94 & 0.18 & 0.20 & 0.95 & 0.23 & 0.95 & 0.19 & 0.31 \\
\hline \multirow{14}{*}{$\begin{array}{l}\text { Unidad 2: Otros } \\
\text { Problemas de Salud de } \\
\text { los Pacientes } \\
\text { Transgénero }\end{array}$} & K 2.1 & 0.28 & 0.45 & 0.28 & 0.06 & 0.05 & 0.53 & 0.50 & 0.53 & 0.44 & 0.29 \\
\hline & K 2.2 & 0.67 & 0.47 & 0.67 & 0.41 & 0.21 & 0.79 & 0.41 & 0.79 & 0.13 & 0.08 \\
\hline & K 2.3 & 0.08 & 0.27 & 0.08 & 0.12 & 0.18 & 0.21 & 0.41 & 0.21 & 0.13 & 0.02 \\
\hline & K 2.4 & 0.94 & 0.24 & 0.94 & -0.06 & -0.06 & 0.88 & 0.33 & 0.88 & 0.13 & 0.18 \\
\hline & K 2.5 & 0.66 & 0.48 & 0.66 & 0.47 & 0.39 & 0.74 & 0.44 & 0.74 & 0.38 & 0.38 \\
\hline & K 2.6 & 0.56 & 0.50 & 0.56 & 0.18 & 0.19 & 0.64 & 0.49 & 0.64 & 0.56 & 0.44 \\
\hline & K 2.7 & 0.38 & 0.49 & 0.38 & 0.65 & 0.45 & 0.66 & 0.48 & 0.66 & 0.38 & 0.36 \\
\hline & K 2.8 & 0.38 & 0.49 & 0.38 & 0.59 & 0.47 & 0.90 & 0.31 & 0.90 & 0.25 & 0.32 \\
\hline & K 2.9 & 0.11 & 0.31 & 0.11 & -0.12 & -0.27 & 0.53 & 0.50 & 0.53 & -0.13 & -0.05 \\
\hline & K 2.10 & 0.36 & 0.48 & 0.36 & 0.65 & 0.51 & 0.81 & 0.40 & 0.81 & 0.25 & 0.30 \\
\hline & K 2.11 & 0.81 & 0.39 & 0.81 & 0.24 & 0.31 & 0.62 & 0.49 & 0.62 & 0.44 & 0.37 \\
\hline & K 2.12 & 0.14 & 0.35 & 0.14 & -0.06 & -0.09 & 0.16 & 0.37 & 0.16 & 0.25 & 0.28 \\
\hline & K 2.13 & 0.72 & 0.45 & 0.72 & 0.29 & 0.29 & 0.86 & 0.35 & 0.86 & 0.38 & 0.39 \\
\hline & K 2.14 & 0.84 & 0.37 & 0.84 & 0.12 & 0.11 & 0.88 & 0.33 & 0.88 & 0.25 & 0.30 \\
\hline \multirow{13}{*}{$\begin{array}{c}\text { Unidad 3: Terapia } \\
\text { Hormonal para la } \\
\text { Transición de Género }\end{array}$} & K 3.1 & 0.42 & 0.50 & 0.42 & 0.41 & 0.31 & 0.62 & 0.49 & 0.62 & 0.25 & 0.29 \\
\hline & K 3.2 & 0.52 & 0.50 & 0.52 & 0.41 & 0.39 & 0.74 & 0.44 & 0.74 & 0.31 & 0.41 \\
\hline & K 3.3 & 0.38 & 0.49 & 0.38 & 0.29 & 0.26 & 0.91 & 0.28 & 0.91 & 0.31 & 0.55 \\
\hline & K 3.4 & 0.77 & 0.43 & 0.77 & 0.35 & 0.29 & 0.91 & 0.28 & 0.91 & 0.25 & 0.38 \\
\hline & K 3.5 & 0.45 & 0.50 & 0.45 & 0.29 & 0.26 & 0.90 & 0.31 & 0.90 & 0.25 & 0.37 \\
\hline & K 3.6 & 0.84 & 0.37 & 0.84 & 0.06 & 0.08 & 0.97 & 0.18 & 0.97 & 0.06 & 0.27 \\
\hline & K 3.7 & 0.28 & 0.45 & 0.28 & 0.29 & 0.14 & 0.33 & 0.47 & 0.33 & 0.44 & 0.41 \\
\hline & K 3.8 & 0.34 & 0.48 & 0.34 & 0.35 & 0.30 & 0.67 & 0.47 & 0.67 & 0.31 & 0.37 \\
\hline & K 3.9 & 0.36 & 0.48 & 0.36 & 0.29 & 0.23 & 0.47 & 0.50 & 0.47 & 0.44 & 0.38 \\
\hline & K 3.10 & 0.27 & 0.45 & 0.27 & 0.29 & 0.20 & 0.84 & 0.37 & 0.84 & 0.13 & 0.22 \\
\hline & K 3.11 & 0.34 & 0.48 & 0.34 & 0.24 & 0.12 & 0.71 & 0.46 & 0.71 & 0.63 & 0.44 \\
\hline & K 3.12 & 0.64 & 0.48 & 0.64 & 0.24 & 0.24 & 0.67 & 0.47 & 0.67 & 0.44 & 0.39 \\
\hline & K 3.13 & 0.77 & 0.43 & 0.77 & 0.47 & 0.50 & 0.88 & 0.33 & 0.88 & 0.19 & 0.38 \\
\hline
\end{tabular}




\begin{tabular}{|c|c|c|c|c|c|c|c|c|c|c|c|}
\hline \multirow{2}{*}{ Unidad } & \multirow{2}{*}{ Item } & \multicolumn{5}{|c|}{ Pre-Prueba } & \multicolumn{5}{|c|}{ Post-Prueba } \\
\hline & & $\bar{x}$ & SD & IDI & ID & ITC & $\bar{x}$ & SD & IDI & ID & ITC \\
\hline & K 3.14 & 0.31 & 0.47 & 0.31 & 0.29 & 0.32 & 0.72 & 0.45 & 0.72 & 0.44 & 0.43 \\
\hline & K 3.15 & 0.38 & 0.49 & 0.38 & 0.53 & 0.42 & 0.48 & 0.50 & 0.48 & 0.69 & 0.48 \\
\hline & K 3.16 & 0.33 & 0.47 & 0.33 & 0.41 & 0.39 & 0.76 & 0.43 & 0.76 & 0.50 & 0.43 \\
\hline & K 3.17 & 0.66 & 0.48 & 0.66 & 0.29 & 0.35 & 0.67 & 0.47 & 0.67 & 0.19 & 0.25 \\
\hline & K 3.18 & 0.13 & 0.33 & 0.13 & 0.06 & 0.13 & 0.79 & 0.41 & 0.79 & 0.38 & 0.39 \\
\hline & K 3.19 & 0.86 & 0.35 & 0.86 & 0.18 & 0.28 & 0.86 & 0.35 & 0.86 & 0.31 & 0.36 \\
\hline & K 3.20 & 0.16 & 0.37 & 0.16 & 0.00 & 0.00 & 0.62 & 0.49 & 0.62 & 0.38 & 0.30 \\
\hline & K 3.21 & 0.16 & 0.37 & 0.16 & -0.06 & -0.03 & 0.19 & 0.40 & 0.19 & 0.38 & 0.34 \\
\hline
\end{tabular}

$\bar{x}=$ mean score; $\mathrm{SD}$ = standard deviation; IDI = item difficulty index; ID = item discrimination; ITC $=$ item-total correlation .

\section{References}

1. Taber, K.S. The Use of Cronbach's Alpha When Developing and Reporting Research Instruments in Science Education. Res. Sci. Educ. 2017, 48, 1273-1296. [CrossRef]

2. Taber, K.S. Classroom-Based Research and Evidence-Based Practice: An Introduction, 2nd ed.; Sage: London, UK, 2013.

3. Eckstein, M.A.; Newsome, C.E.; Borrego, M.; Burnett, A.E.; Wittstrom, K.; Conklin, J. A cross-sectional survey evaluating transgender-related care education in United States pharmacy school curricula. Curr. Pharm. Teach. Learn. 2019, 11, 782-792. [CrossRef] [PubMed]

4. Leach, C.; Layson-Wolf, C. Survey of community pharmacy residents' perceptions of transgender health management. J. Am. Pharm. Assoc. 2016, 56, 441-445. [CrossRef] [PubMed]

5. Wilkening, G.L. The current status of transgender health education in doctor of pharmacy curricula in North America. Ment. Health Clin. 2017, 7, 168-171. [CrossRef] [PubMed]

6. Grundmann, O.; Segal, R.; Pullo, J.; Davis, L.; Felix-Irizarry, Y.; Da Silva, L.; Holets, T. The Pharmacist as an LGBTQ Ally. Am. J. Pharm. Educ. 2020, 84. [CrossRef]

7. Llayton, C.K.; Caldas, L.M. Strategies for inclusion of lesbian, gay, bisexual, transgender, queer, intersex, and asexual (LGBTQIA+) education throughout pharmacy school curricula. Pharm. Pract. 2020, 18, 1862. [CrossRef]

8. Melin, K.; Hilera-Botet, C.R.; Vega-Vélez, D.; Salgado-Crespo, V.M.; Santiago, D.; Hernández-Agosto, J.; Muñoz-Burgos, A.; Cajigas, Z.; Martínez-Vélez,J.J.; Rodríguez-Díaz, C.E. Readiness to provide pharmaceutical care to transgender patients: Perspectives from pharmacists and transgender individuals. J. Am. Pharm. Assoc. 2019, 59, 651-659. [CrossRef]

9. Grant, J.M.; Mottet, L.A.; Tanis, J.; Harrison, J.; Herman, J.L.; Keisling, M. Injustice at Every Turn: A Report of the National Transgender Discrimination Survey. Available online: http://transequality.org/PDFs/NTDS_Report.pdf\$delimiter"026E30F\$nhttp://2fwww.thetaskforce. org/downloads/resources_and_tools/ntds_report_on_health.pdf (accessed on 31 August 2020).

10. UCSF. Guidelines for the Primary and Gender-Affirming Care of Transgender and Gender Nonbinary People, 2nd ed.; Deutsch, M.B., Ed.; Center of Excellence for Transgender Health: San Francisco, CA, USA, 2016.

11. Safer, J.D.; Coleman, E.; Feldman, J.; Garofalo, R.; Hembree, W.; Radix, A.; Sevelius, J. Barriers to healthcare for transgender individuals. Curr. Opin. Endocrinol. Diabetes Obes. 2016, 23, 168-171. [CrossRef]

12. Kelley, L.; Chou, C.L.; Dibble, S.L.; Robertson, P.A. A Critical Intervention in Lesbian, Gay, Bisexual, and Transgender Health: Knowledge and Attitude Outcomes among Second-Year Medical Students. Teach. Learn. Med. 2008, 20, 248-253. [CrossRef]

13. Banerjee, S.C.; Walters, C.B.; Staley, J.M.; Alexander, K.; Parker, P. Knowledge, Beliefs, and Communication Behavior of Oncology Health-care Providers (HCPs) regarding Lesbian, Gay, Bisexual, and Transgender (LGBT) Patient Health care. J. Health Commun. 2018, 23, 1-11. [CrossRef] 
14. Dy, G.W.; Osbun, N.C.; Morrison, S.D.; Grant, D.W.; Merguerian, P.A. Exposure to and Attitudes Regarding Transgender Education Among Urology Residents. J. Sex. Med. 2016, 13, 1466-1472. [CrossRef] [PubMed]

15. Rowan, S.P.; Lilly, C.L.; Shapiro, R.E.; Kidd, K.M.; Elmo, R.M.; Altobello, R.A.; Vallejo, M.C. Knowledge and Attitudes of Health Care Providers Toward Transgender Patients Within a Rural Tertiary Care Center. Transgender Health 2019, 4, 24-34. [CrossRef] [PubMed]

16. Colton, D.; Covert, R.W. Designing and Constructing Instruments for Social Research and Evaluation, 3rd ed.; John Wiley \& Sons, Inc.: San Francisco, CA, USA, 2007.

17. ESCO Group. Available online: https://www.escogroup.org/hvac/examdevelopment.aspx (accessed on 17 June 2020).

18. Clark, L.A.; Watson, D. Constructing Validity: Basic Issues in Objective Scale Development. Psychol. Assess. 1995, 7, 309-319. [CrossRef]

19. Boateng, G.O.; Neilands, T.B.; Frongillo, E.A.; Melgar-Quiñonez, H.R.; Young, S.L. Best Practices for Developing and Validating Scales for Health, Social, and Behavioral Research: A Primer. Front. Public Health 2018, 6. [CrossRef]

20. Coleman, E.; Bockting, W.; Botzer, M.; Cohen-Kettenis, P.; Decuypere, G.; Feldman, J.; Fraser, L.; Green, J.; Knudson, G.; Meyer, W.J.; et al. Standards of Care for the Health of Transsexual, Transgender, and Gender-Nonconforming People, Version 7. Int. J. Transgenderism 2012, 13, 165-232. [CrossRef]

21. Domínguez-Lara, S.A.; Merino-Soto, C. ¿Por qué es importante reportar los intervalos de confianza del coeficiente alfa de Cronbach? Rev. Latinoam. Cienc. Soc. Niñez Juv. 2015, 13, 1326-1328.

22. Matlock-Hetzel, S. Basic Concepts in Item and Test Analysis. Available online: http://ericae.net/ft/tamu/Espy. htm (accessed on 3 July 2020).

23. Caycho-Rodríguez, T. Intervalos de Confianza para el coeficiente alfa de Cronbach: Aportes a la investigación pediátrica. Acta Pediátrica México 2017, 38, 291. [CrossRef]

24. Thompson, B.; Levitov, J.E. Using microcomputers to score and evaluate test items. Coll. Microcomput. 1985, 3, 163-168.

25. Berger, R.; Hänze, M. Impact of Expert Teaching Quality on Novice Academic Performance in the Jigsaw Cooperative Learning Method. Int. J. Sci. Educ. 2014, 37, 294-320. [CrossRef]

26. Bretz, S.L.; McClary, L. Students' Understandings of Acid Strength: How Meaningful Is Reliability When Measuring Alternative Conceptions? J. Chem. Educ. 2014, 92, 212-219. [CrossRef]

27. Ledesma, R.D. AlphaCI: Un programa de cálculo de intervalos de confianza para el coeficiente alfa de Cronbach. Psico-USF 2004, 9, 31-37. [CrossRef]

28. Confidence Intervals for a Sample Cronbach Coefficient Alpha Value Calculator. Available online: https: //www.psyctc.org/stats/R/Feldt1.html (accessed on 3 July 2020).

29. Schmitt, N. Uses and abuses of coefficient alpha. Psychol. Assess. 1996, 8, 350-353. [CrossRef] 